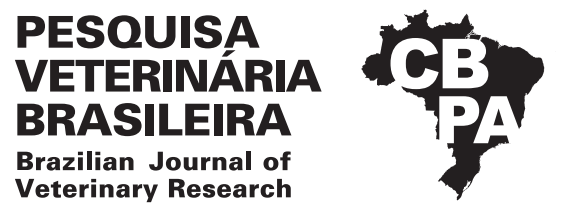

Pesq. Vet. Bras. 38(9):1834-1837, setembro 2018 DOI: 10.1590/1678-5150-PVB-5447

Original Article

ISSN 0100-736X (Print)

ISSN 1678-5150 (Online)

\title{
Suture and venous traction test analysis in dogs fixed in alcohol and preserved in saline solution ${ }^{1}$
}

\author{
Marina E.S. Pelógia², Eduardo S.F. Cerqueira² ${ }^{2}$, Camila P.B. Silveira ${ }^{3}$, \\ Glauco S. Rolim ${ }^{4}$, Alisson D.S. Fechis ${ }^{2}$, Thiago A.S.S. Rocha² ${ }^{2}$ José L. Laus ${ }^{3}$ \\ and Fabrício S. Oliveira ${ }^{2 *}$
}

\begin{abstract}
Pelógia M.E.S., Cerqueira E.S.F., Silveira C.P.B., Rolim G.S., Fechis A.D.S., Rocha T.A.S.S., Laus J.L. \& Oliveira F.S. 2018. Suture and venous traction test analysis in dogs fixed in alcohol and preserved in saline solution. Pesquisa Veterinária Brasileira 38(9):18341837. Universidade Estadual Paulista, Via de acesso Paulo Donato Castelane, Jaboticabal, SP 14884-900, Brazil. E-mail: singaretti@fcav.unesp.br

The objective of this research was to determine in necropsied dogs the best time for fixation in ethylic alcohol (EA) and preservation in 30\% sodium chloride aqueous solution (SCAS 30\%), aiming micro-surgical training. Five groups of necropsied dogs (G1 to G5) were fixed with EA, and put in boxes containing EA for 30 (G2), 60 (G3), 90 (G4) or 120 days (G5). After that, each group was preserved in SCAS 30\% for 120 days. The control group (G1) was composed by cadavers without fixation/preservation. At the end of each period, two fragments of external jugular vein per cadaver were collected, for traction test. Immediately after the collection, the cadavers femoral veins were evaluated (by 2 people) regarding the suture quality in binocular surgical microscope, and attributed scores from 0 (bad) to 5 (excellent), regarding the fresh samples. The average at the maximum rupture strength of the G3 fixation end $(21.51 \mathrm{~N})$, such as the average of the G2 preserving end $(21.62 \mathrm{~N})$ remained closer to the control group (19.98N) and the G2 was the group with the best score for venous suture training. The EA was efficient as a fixative just like SCAS as a dog cadavers' preservative. The small change of the traction test values, together with the best suture score, indicated the group kept for 30 days in EA and SCAS (G2) as the best for venous micro-surgical training.
\end{abstract}

INDEX TERMS: Suture, venous traction test, dogs, saline solution, canine, conservation, preservation, surgery, training.

RESUMO.- [Análise de sutura e de teste de tração venosa em cães fixados em álcool e conservados em solução salina.]0 objetivo deste trabalho foi determinar, em cadáveres de cães, o melhor tempo para fixação em álcool etílico (AE) e conservação em solução aquosa de cloreto de sódio (SACS) a 30\% visando o treinamento microcirúrgico. Cadáveres de cinco grupos (G1 a G5) foram fixados com AE e colocados

\footnotetext{
${ }^{1}$ Received on November 08, 2017.

Accepted for publication on November 22, 2017.

${ }^{2}$ Departamento de Morfologia e Fisiologia Animal, Faculdade de Ciências Agrárias e Veterinárias (FCAV), Universidade Estadual Paulista (Unesp), Via de acesso Prof. Paulo Donato Castellane, Jaboticabal, SP 14884-900, Brazil. *Corresponding author: singaretti@fcav.unesp.br

${ }^{3}$ Departamento de Clínica e Cirurgia Veterinária, Faculdade de Ciências Agrárias e Veterinárias (FCAV), Universidade Estadual Paulista (Unesp), Via de acesso Prof. Paulo Donato Castellane, Jaboticabal, SP 14884-900.

${ }^{4}$ Departamento de Ciências Exatas, Faculdade de Ciências Agrárias e Veterinárias (FCAV), Universidade Estadual Paulista (Unesp), Via de acesso Prof. Paulo Donato Castellane, Jaboticabal, SP 14884-900.
}

em caixas contendo AE por 30 (G2), 60 (G3), 90 (G4) ou 120 days (G5). Depois, cada grupo foi conservado em SACS $30 \%$ por 120 dias. 0 grupo controle (G1) foi composto de cães sem fixação/conservação. Ao final de cada período, 2 fragmentos da veia jugular externa por cadáver foram coletados para o teste de tração. Imediatamente após a coleta, as veias femorais foram avaliadas (por 2 pessoas) em relação à qualidade da sutura em microscópio cirúrgico binocular, e atribuídos escores de 0 (péssimo) à 5 (excelente), em relação às amostras frescas. A média da força máxima de ruptura no G3 no final da fixação $(21,51 \mathrm{~N})$, assim como a média do G2 no final da conservação $(21,62 \mathrm{~N})$ foram as que mais se mantiveram próxima do grupo controle $(19,98 \mathrm{~N})$ e o G2 foi o grupo com o melhor escore para treinamento da sutura venosa. $\mathrm{O} \mathrm{AE}$ foi eficiente como fixador assim como a SACS foi efetiva na conservação de cadáveres de cães. A pequena alteração nos valores do teste de tração, junto com o melhor escore para sutura, indicaram o grupo mantido por 30 dias 
em AE e SACS (G2) como o melhor para treinamento venoso microcirúrgico.

TERMOS DE INDEXAÇÃO: Sutura, teste de tração venosa, álcool, solução salina, caninos, conservação, preservação, cirurgia, treinamento.

\section{INTRODUCTION}

Nowadays, various are the alternative methods that look for the animal's welfare in the veterinary surgical technique teaching. Such methods aim to substitute the use of live animals, without affecting the learning, generating similar or superior learning to the students (Silva et al. 2007). A negative emotional state may make it difficult more complex cognitive mechanisms, which means, disrupting a significant learning (Paixão 2008).

There are examples of fixative solutions that are capable of preserving cadavers for surgical use, among them, the Thiel solution (Groscurth et al. 2001), the Klotz solution (Rodrigues 2010), the modified Larssen solution (Silva et al. 2004) and all have formalin. The Larssen solution is described as a preservative solution that keeps the original consistency, color and characteristics of the biological material and is capable of removing blood clots (Sampaio 1989) and there is no liquid glycerin (Menezes 2012).

Many papers have been demonstrating the efficacy of using chemically prepared cadavers for use in veterinary surgery classes (Silva et al. 2004); it provides a student's wider acceptance as well as a better learning. To perform such procedure, animals that died in shelters, clinics and veterinary hospitals that would be discarded, might be used as animals' substitutes (Silva et al. 2007, Mathews et al. 2010).

There were no significant differences in the surgical performance in veterinary medicine students that worked in cadavers and live animals (Carpenter et al. 1991, Silva et al. 2007). Regarding the surgical learning in chemically preserved cadavers, $88.9 \%$ of veterinary medicine students reported that teaching was very satisfactory, while $5.9 \%$ thought it would be more efficient if the learning was in live animals. Regardless of the chemical procedure used for cadaver's preservation, $95.7 \%$ of the students approved the use of cadavers in surgery learning (Silva et al. 2007). The objective of this work was to determine, in necropsied dogs, the best fixative period in ethylic alcohol (EA) and preservation in sodium chloride aqueous solution 30\% (SCAS 30\%), aiming the venous micro-surgical training.

\section{MATERIALS AND METHODS}

Necropsied dogs. Forty adults, male and female dog cadavers were used, from the Center of Zoonosis Control of Ribeirão Preto/ SP, Brazil, in a process previous approved by the Legal Department (process 02.2014.000027-1). The animals were frozen (freezer at $-18^{\circ} \mathrm{C}$ ) after death and then transported to the Laboratory of Surgical Anatomy of the Unesp Jaboticabal/SP, located $50 \mathrm{~km}$ away.

The animals were between 5 and $12 \mathrm{~kg}$ of body weight in order to facilitate the handling in the laboratory, and presented body score 4 (easily palpable ribs, with minimum fat cover) or 5 (palpable ribs and without fat cover excess, abdominal waist observed caudally to the ribs when dorsally seen; evident abdominal fold when seen laterally, in a scale from 1 to 9 , considered as an ideal body score (Laflamme 1997).

Anatomic technique applied. After 15 days from the death, the animals were thawed in horizontal freezers (used in the positive temperature function) at $4-6^{\circ} \mathrm{C}$, weighted and then randomly divided in groups for the fixation with ethylic alcohol $96^{\circ} \mathrm{GL}$, for each kilogram of weight, the animals received $120 \mathrm{~mL}$ of fixative solution $(95 \%$ of alcohol and $5 \%$ of glycerin), via external common carotid artery. The glycerin in low quantity was used only for obtaining a higher visceral malleability. After that, they were divided in groups that remained in different times under fixation (except the group 1) before being kept preserved in sodium chloride aqueous solution $30 \%$ :

Group 1: control group with 8 necropsied dogs, from which tissue samples were taken out for analysis and that were not submitted to fixation; fresh cadavers.

Group 2: 8 necropsied dogs that remained under fixation for 30 days in the alcohol solution. After this period, they remained for 30 days in the SCAS $30 \%$.

Group 3: 8 necropsied dogs that remained under fixation for 60 days in the alcohol solution. After this period, they remained for 60 days in the SCAS 30\%.

Group 4: 8 necropsied dogs that remained under fixation for 90 days in the alcohol solution. After this period, they remained for 90 days in the SCAS $30 \%$.

Group 5: 8 necropsied dogs that remained under fixation for 120 days in the alcohol solution. After this period, they remained for 120 days in the SCAS $30 \%$.

Eight plastic boxes, with lids, 310 liters, were used for storing the animals, both during the fixation procedure in alcohol and during storage in sodium chloride aqueous solution $30 \%$. For each group, one box was used during the fixation phase and during the conservation, which were kept in covered environment, but opened in the sides and with abundant ventilation, without igneous sources nearby, avoiding any kind of local accident.

Analysis regarding the vein resistance. For evaluating the tissue resistance, an Assay Universal Machine (EMIC ${ }^{\circledR}$ DL-2000, Brazil) was used. A 50N-charge cell was used and the charge application speed of $10 \mathrm{~mm} / \mathrm{min}$, with $10 \mathrm{~mm}$ clearance between the material gripping claws.

Because of the external jugular vein length of the cadavers used was small, making it difficult the traction analysis in the assay machine, vascular analysis ( 2 fragments of $4 \mathrm{~cm}$ per animal/moment) were performed in the:

Moment Zero: in necropsied dogs from the control-group, without any fixative - fresh animals,

Fixation Moment: after the fixation period of each group (1 month to 4 months),

Preserving Moment: fragments collection was made in sodium chloride aqueous solution in period equivalent to the same fixation period in alcohol. Thus, necropsied dogs fixed for 1 month had their external jugular veins evaluated after 1 month in the sodium chloride aqueous solution; animals fixed for 2 months had their external jugular veins evaluated after 2 months in the sodium chloride aqueous solution, and so on. The evaluated blood vessel fragment was longitudinally opened to look like a rectangular tape at the biomechanical evaluation. 
Statistic. At the end of the experiment, a comparison between the groups was made concerning the time in the fixative solution using ANOVA and Tukey test $(\mathrm{p}<0.05)$ between the groups.

Vascular suture analysis. The femoral veins were analyzed regarding the suture in the same moments predicted to the biomechanical analysis of the external jugular veins. It was chosen another vein for the vascular analysis regarding the suture, because there was no viable length to proceed it in the same vein from the biomechanical analysis. For this, the pelvic limbs were disarticulated from the thigh and taken to the training sector in ophthalmology from the Department Veterinary Clinics and Surgery of the University. A Desk Binocular Surgical Microscope (UM-M4, DF Vasconcelos ${ }^{\circledR}$, Brazil) and needle-suture thread type Nylon 8-0 (Mononylon Ethicon Inc $^{\circledR}$, USA) were used. For the suture, single separated stitches were used and the femoral veins were evaluated regarding the malleability and resistance for the suture procedure. Scores were attributed as 1 (very bad), 2 (bad), 3 (moderate), 4 (good), 5 (excellent).

In the venous test at the surgical microscope, the evaluation was always carried out by an under graduating student and a professional, after 3 training sessions of 2 hours, in different days, for adapting to the equipment and to the suture technique, aiming to minimize interpretation mistakes of the evaluated vascular material quality. Always when it came to the evaluation day, a fragment preserved in alcoholic or saline solution, a similar fragment to a fresh cadaver and without any fixative, was used for comparing the sutures quality.

\section{RESULTS}

All the results regarding the average maximum rupture strength of the jugular veins traction tests, as well as the vascular suture scores in surgical microscope, are presented hereupon (Table 1 to 3 ).

There was no difference (ANOVA, Table 2 and 3) among control and alcohol groups $(\mathrm{p}=0.5734)$ or control and saline solution groups $(\mathrm{p}=0.0683)$ as for traction tests. However, G2 presented small variation as for maximum rupture strength and values closer to the control group in the final of conservation time, besides presented the highest attributed score occurred in the group 2 (Table 4), which means that the femoral veins of the animals that remained 30 days under alcoholic fixation and 30 days in the sodium chloride aqueous preservation solution 30\% exhibited results close to fresh vessels for the vascular suture practice in surgical microscope.

Table 1. Averages of maximum rupture strength, in $\mathrm{N}$, of the traction tests of the dogs' external jugular from the groups fixed with alcohol and conserved in sodium chloride aqueous solution $30 \%$

\begin{tabular}{lccccc}
\hline & G1 & G2 & G3 & G4 & G5 \\
\hline Final fixation & \multirow{2}{*}{$19.98 \pm 11.49$} & $26.17 \pm 12.50(\mathrm{p}=0.72)$ & $21.51 \pm 7.30(\mathrm{p}=0.99)$ & $24.44 \pm 14.00(\mathrm{p}=0.76)$ & $23.40 \pm 10.21(\mathrm{p}=0.98)$ \\
Final preservation & & $21.62 \pm 9.38(\mathrm{p}=0.99)$ & $10.76 \pm 7.54(\mathrm{p}=0.33)$ & $14.79 \pm 10.68(\mathrm{p}=0.87)$ & $16.40 \pm 7.99(\mathrm{p}=0.96)$
\end{tabular}

$\overline{\mathrm{G} 1}$ = group without fixative or preservative (fresh samples), G2 = alcoholic fixation and saline preservation for 30 days, G3 = alcoholic fixation and saline preservation for 60 days, G4 = alcoholic fixation and saline preservation for 90 days, G5 = alcoholic fixation and saline preservation for 120 days. There were no differences among groups (G2-G5) when compared to the control group (G1) and p values were always higher than 0.05 .

Table 2. Variance analysis (Anova) of the traction test from the dogs' external jugular vein from the groups fixed with alcohol/glycerin in different periods $(30,60,90$ and 120 days $)$

\begin{tabular}{lccccc}
\hline \multicolumn{1}{c}{ Variation source } & SS & LD & MS & F & 0.731 \\
\hline Between groups & 378 & 4 & 94.50 & 129.2 & \\
Inside groups & 9,692 & 75 & & & \\
TOTAL & 10,070 & 79 & &
\end{tabular}

$\overline{\mathrm{SS}}=$ Square sum, $\mathrm{LD}=$ liberty degree, $\mathrm{MS}=$ medium square, $\mathrm{F}=$ calculated $\mathrm{F}, \mathrm{P}=$ minimal significance level.

Table 3. Variance analysis (Anova) of the traction test from the dogs' external jugular vein from the groups fixed with alcohol/glycerin after kept in sodium chloride aqueous solution in different periods $(30,60,90$ and 120 days)

\begin{tabular}{lcccc}
\hline \multicolumn{1}{c}{ Variation source } & SS & LD & MS & F \\
\hline Between groups & 722.8 & 4 & 193.20 & 2.288 \\
Inside groups & 5,995 & 71 & 84.43 & 0.0683 \\
TOTAL & 6,767 & 75 & &
\end{tabular}

$\overline{\mathrm{SS}}=$ Square sum, $\mathrm{LD}=$ liberty degree, $\mathrm{MS}=$ medium square, $\mathrm{F}=$ calculated $\mathrm{F}, \mathrm{P}=$ minimal significance level.

Table 4. Scores average ( 1 very bad, 2 bad, 3 moderate, 4 good, 5 excellent) attributed to the femoral vein suture in necropsied dogs fixed in alcohol and preserved in sodium chloride aqueous solution for different periods

\begin{tabular}{lccccc}
\hline & G1 & G2 & G3 & G4 & G5 \\
\hline Alcohol & 5 & 4 & 3 & 3.5 & 4 \\
Salt & & 3.5 & 3 & 3 & 3
\end{tabular}

G1 = fresh samples, without fixative or conservative substances, G2 $=30$ days' fixation and preservation, G3 = 60 days' fixation and preservation, G4 $=90$ days' fixation and preservation, G5 = 120 days' fixation and preservation. 


\section{DISCUSSION AND CONCLUSION}

The ethylic alcohol has shown to be efficient as dog cadaver's fixative, allowing good preservation and avoiding material deterioration, as described in the literature (Rodrigues 2010). Still, alcohols used in human corpses fixation for 6 months to 1-year period maintain the tissue quality similar to the fresh tissue (Goyri-O'Neill et al. 2013), similarly to what was observed in our results, especially in alcoholic fixation and preservation in SCAS for 30 days in dog cadavers, through venous traction test and body score analysis.

Biomechanical effects in animal tissues were already observed when the fixative agent was the formaldehyde, which caused a big material stiffening in analysis of 45 days ( 7 fold) (Guastalli et al. 2007) or up to one year ( 4.4 to 5 fold) (Guastalli et al. 2012). When the ethylic alcohol is used as fixative, tissue stiffening increase also occurs, making it almost five fold stiffer at cutting during the first six months, and three fold stiffer after one year of immersion in the preservative agent (Nunes et al. 2011). However, in this project, although the ethylic alcohol has been used as fixative, there were few changes regarding the traction tests in the external jugular veins, and the values of the group considered as ideal for venous micro-surgical training varied about $30 \%$ in relation to the control group, although there was no statistical difference. Regarding the preservation in SCAS 30\% for the same period, there was also no statistical difference in relation to the control group.

The SCAS $30 \%$ showed to be extremely efficient in preserving the fixed tissues (Oliveira 2014), not observing apparent contamination during the analyzed period.

The use of chemically prepared cadavers for students' surgical training from the Veterinary Medicine course fits perfectly in a new tendency and involves alternative and ethic methods for teaching. Therefore, many universities from Canada and the United States have already avoided that thousands of dogs were submitted to the euthanasia in the period from 1983 to 1984 (Balcombe 2000).

Acknowledgements.- FAPESP, process 2015/07939-6 and 2015/08259.

\section{REFERENCES}

Balcombe J. 2000. The use of animals in higher education: problems, alternatives and recommendations. Humane Society Press, Washington. 104p.

Carpenter L.G., Piermattei D.L., Salman M.D., Orton C., Nelson A.W., Smeak D.D., Jennings P.B. \& Taylor R.A. 1991. A comparison of surgical training with live anesthezed dogs and cadavers. Vet. Surg. 20(6):373-378. <http:// dx.doi.org/10.1111/j.1532-950X.1991.tb00342.x><PMid:1369518>
Goyri-O’Neill J., Pais D., Freire De Andrade F., Ribeiro P., Belo A., O’Neill A., Ramos S. \& Neves Marques C. 2013. Improvement of the embalming perfusion method: The innovation and the results by light and scanning electron microscopy. Acta Med. Port. 26(3):188-194. <PMid:23815830>

Groscurth P., Eggli P., Kapfhammer J., Rager G.J., Hornung P. \& Fasel J.D.H. 2001. Gross anatomy in the surgical curriculum in Switzerland: improved cadaver preservation, anatomical models, and course development. Anat. Rec. 265(6):254-256.<http://dx.doi.org/10.1002/ar.10030><PMid:11753916>

Guastalli B.H.L., Saddi L.G.C., Zani F.L., Nunes T.C., Gamon T.H.M. \& Oliveira F.S. 2007. Mensuração da textura de tecido muscular fixado e conservado em solução aquosa de formaldeído por 45 dias. $34^{\circ}$ Congresso Brasileiro de Veterinária, Santos, SP.

Guastalli B.H.L., Nunes T.C., Gamón T.H.M., Do Carmo L.G., Oliveira F.S. \& Del Quiqui E.M. 2012. Quantificação do enrijecimento muscular de peito de frango causado por formaldeído. Biotemas 25:195-197.

Laflamme D.P. 1997. Development and validation of a body condition score system for dogs. Canine Pract. 22:10-15.

Mathews K.G., Riley K., Lascelles B.D.X. \& Dernell W.S. 2010. Preparation of canine and feline cadavers for surgical laboratories. Vet. Surg. 39(2):224-225. <http://dx.doi.org/10.1111/j.1532-950X.2009.00586.x><PMid:20210970>

Menezes C.L.M. 2012. Preservação de cadáver de coelho (Oryctolagus cuniculus) com a solução de Larssen modificada para treinamento em cirurgia videolaparoscópica. Dissertação de Mestrado em Morfologia, Cirurgia e Patologia Animal, Programa de Pós-Graduação em Ciências Veterinárias, Faculdade de Veterinária, Universidade Federal do Rio Grande do Sul. 82p.

Nunes T.C., Oliveira F.S., Gamón T.H.M., Guastalli B.H.L., Carmo L.G. \& Del Quiqui E.M. 2011. Análise da textura de músculos peitorais submetidos a fixação e conservação em álcool. Braz. J. Vet. Res. Anim. Sci. 48(6):464-467. <http://dx.doi.org/10.11606/S1413-95962011000600004>

Oliveira F.S. 2014. Assessing the effectiveness of 30\% sodium chloride aqueous solution for the preservation of fixed anatomical specimens: a 5-year follow-up study. J. Anat. 225(1):118-121. <http://dx.doi.org/10.1111/ joa.12185> <PMid:24762210>

Paixão R.L. 2008. Métodos substitutivos ao uso de animais vivos no ensino: repensando o que aprendemos com os animais no ensino. Ciênc. Vet. Trop. 11:88-91.

Rodrigues H. 2010. Técnicas Anatômicas. GM Gráfica \& Editora, Vitória, ES. 269p.

Sampaio F.J.B. 1989. Estudo do crescimento do rim humano durante o período fetal. Tese de Doutorado em Morfologia, Escola Paulista de Medicina, São Paulo. 102p.

Silva R.M.G., Matera J.M. \& Ribeiro A.A.C.M. 2004. Preservation of cadavers for surgical technique training. Vet. Surg. 33(6):606-608. <http://dx.doi. org/10.1111/j.1532-950x.2004.04083.x> <PMid:15659015>

Silva R.M.G., Matera J.M. \& Ribeiro A.A.C.M. 2007. New alternative methods to teach surgical techniques for veterinary medicine students despite the absence of living animals: is that an academic paradox? Anat. Histol. Embryol. 36(3):220-224. <http://dx.doi.org/10.1111/j.1439-0264.2007.00759.x> $<$ PMid:17535356> 